\title{
Fatihunnada*
}

Universitas Islam Negeri Syarif Hidayatullah Jakarta, Indonesia

\section{Iffatul Umniati}

Universitas Islam Negeri Syarif Hidayatullah Jakarta, Indonesia

\section{Respiani}

Tau-Data, Indonesia

\begin{abstract}
Fatwa Majelis Ulama Indonesia (MUI) sering menjadi kontroversi di tengah masyarakat, termasuk fatwa haram golput (golongan putih; tidak memilih) pada tahun 2009. Fatwa ini menjadi tren perbincangan di media sosial pada ajang Pemilihan Umum 2014. Netizen Twitter memberikan respons yang beragam dengan berbagai sentimen: positif, negatif, dan netral. Data penelitian ini berupa data tweet berbahasa Indonesia dari pengguna Twitter yang diambil pada tahun 2014. Pengambilan data menggunakan modul python, yaitu twitter scraper, yang kemudian disimpan dalam bentuk Comma Separated Values (CSV) yang selanjutnya dilakukan analisis kritis. Dari 1.836 tweet, 830 atau sebanyak $45.21 \%$ mengandung respons netral, 825 atau sebanyak $44.93 \%$ mengandung respons negatif, dan 181 atau $9.86 \%$ mengandung respons positif. Hasil ini menunjukkan bahwa penolakan terhadap fatwa haram golput lebih besar dari pada penerimaannya di kalangan netizen. Penolakan ini diwarnai dengan beberapa isu seperti hukum golput dalam pandangan Islam, dosa antara memilih golput dan pemimpin yang tidak baik, dan politisasi fatwa MUI. Yang lebih penting adalah hasil ini menunjukkan bahwa otoritas MUI dalam berfatwa tidak sepenuhnya didengar dan ditaati oleh Muslim Indonesia.
\end{abstract}

\section{Kata-kata Kunci}

Fatwa, golput, otoritas, Majelis Ulama Indonesia, Twitter, netizen

\footnotetext{
* Penulis untuk korespondensi:

Fatihunnada

Mekarsari Barat, No. 02, Tambun Selatan, Kab. Bekasi, JABAR.

Email: fatihunnada@uinjkt.ac.id
} 


\section{Abstract}

The fatwas of Majelis Ulama Indonesia often incite controversy among Indonesian Muslims. This includes a fatwa on the prohibition of golongan putih (golput; non-voting behavior) that was issued in 2009. This fatwa sparkes heated debates among netizens, inluding Twitter users during the 2014 and 2019 presidential elections. This data required for this research were collected from the Twitter in the form of tweets in several months in 2014 using the python module, namely the twitter scraper which was then stored in the form of Comma Separated Values (CSV). Out of 2,491 tweets, 1,142 tweets or $45.84 \%$ contain neutral responses, 1,071 tweert or $42.95 \%$ contain negative responses, and 278 tweets or $11.16 \%$ contain positive responses. This figure shows that the rejection of the fatwa on the prohibition of golput was greater than its acceptance by netizens. More importantly, this indicate that the authority of MUI in issuing fatwas is not fully accepted and obeyed by Indonesian Muslims.

\section{Key Words}

Fatwa, golput, non-voting behavior, authority, Majelis Ulama Indonesia, Twitter, netizens

\section{Pendahuluan}

Dalam kehidupan beragama di Indonesia, beberapa lembaga keagamaan Islam menerbitkan fatwa terkait persoalan masyarakat Muslim Indonesia. Fatwa merupakan salah satu otoritas keagamaan yang berasal dari ulama yang menyatakan pendapat mereka dari sudut pandang hukum Islam tentang topik-topik yang diajukan oleh umat Islam (Kaptein 2004:115). Dalam berfatwa, ulama mempertimbangkan kondisi terkait orang yang meminta fatwa (mustafti) (Ibn Manzhur $1414 \mathrm{H}:$ 15/147-148; al-Zabidi t.t.: 39/211-212). Majelis Ulama Indonesia (MUI) sebagai lembaga 'semipemerintahan' memiliki otoritas mengeluarkan fatwa melalui Komisi Fatwa (Mudzhar 1993: 47; Bowen 2003: 229). Selain itu, lembagalembaga non-pemerintah juga memiliki otoritas untuk memberikan fatwa seperti Nahdlatul Ulama melalui Lembaga Bahtsul Masail (Barton 1996) dan Muhammadiyah melalui Majlis Tarjih (Anwar 2005: 33-39).

Respons masyarakat terhadap fatwa sangat beragam. Sebagian masyarakat menggunakan legitimasi fatwa untuk melakukan intimidasi kepada kelompok lain baik secara fisik atau verbal seperti fatwa MUI 
tentang kesesatan Ahmadiyah pada tahun 2005 (MUI Fatwa tentang Kesesatan Ahmadiyah 2005) yang berujung pembakaran rumah penduduk Ahamdiyah di Lombok Barat (Assyaukanie 2009:7-10). Sirry menegaskan bahwa fatwa MUI telah mengundang ruang diskusi terbuka yang konstruktif serta membangun di antara masyarakat Indonesia. Hal itu dapat tergambar melalui fatwa MUI tentang perayaan hari Natal (MUI Fatwa tentang Perayaan Natal Bersama: 1981) dan fatwa tentang pluralisme, liberalisme dan sekulerisme (MUI Fatwa tentang Pluralisme, Liberalisme dan Sekularisme Agama: 2005) yang mengundang banyak kontroversi antara pro dan kontra dalam menyikapi fatwa MUI (Sirry 2013:116-117). Abdurrahman Wahid (1981) mengkritisi MUI bahwa fatwa larangan perayaan Natal bersama bukan hal yang harus dijadikan prioritas dan mempertanyakan otoritas MUI untuk melakukan reinterpretasi terhadap sumber agama.

Kajian tentang fatwa di Indonesia tentu saja sudah banyak dilakukan. Di antara kajian yang paling menonjol adalah kajian oleh Nico J. Kaptein (2004). Kaptein mengaji tiga fatwa di Indonesia, yaitu fatwa Ahmad Dahlan di akhir abad ke-19 tentang pelaksanaan salat jumat pada dua masjid yang berdekatan lokasinya, fatwa Ahmad Hasan pada tahun 1930-an tentang penggunaan bedug dan drum sebelum azan untuk memanggil orang melaksanakan salat berjamaah di masjid, dan amanat (sejenis fatwa) pada tahun 1999 tentang Pemilihan Umum untuk mendorong umat Islam memberikan hak pilih pada Pemilihan Umum 1999 untuk melawan bahaya komunis, otoritarian, dan kekuatan sekuler yang terselubung dalam partai politik. Kaptein menguji fatwa-fatwa tersebut dengan analisis kritis terhadap lima aspek dalam fatwa, yaitu pembuat fatwa, jaringan landasan berpikir fatwa, rujukan dan landasan fatwa, bahasa yang digunakan dalam teks fatwa, dan respons masyarakat dalam melaksanakan fatwa. Ia menegaskan bahwa fatwa merupakan salah satu otoritas keagamaan yang hidup di Indonesia karena fatwa lahir dari ulama dalam mengekspresikan pendapat mereka dari sudut pandang hukum Islam tentang beberapa topik yang diajukan oleh umat Islam. Namun, telah terjadi pergeseran otoritas dalam fatwa-fatwa yang terkait dengan permasalahan politik dan kehidupan sosial (Kaptein 2004).

Selain itu, Mun'im Sirry (2013) melakukan penelitian tentang fatwa pelarangan merayakan Natal bersama dan fatwa kesesatan pluralisme, liberalisme dan sekulerisme. Fatwa pelarangan merayakan Natal dianggap sebagai fatwa yang bernuansa politis karena pada masa pemerintahan Suharto masyarakat mulai mengambil jarak dengan pemerintah dalam permasalahan keagamaan sehingga Suharto perlu mengambil langkah untuk mendikte perdebatan umum melalui fatwa MUI tersebut. Sirry melakukan analisa terhadap teks fatwa itu, keadaan yang meliputinya, dan kontroversi yang dihadapi oleh fatwa tersebut. Setelah itu, ia melihat respons masyarakat Indonesia terhadap MUI sebagai lembaga 
pemberi fatwa untuk membentuk karakter Islam Indonesia di masa depan. Ia juga memberikan saran untuk penelitian lebih lanjut melihat respons masyarakat di lapangan terhadap fatwa MUI. Sirry menegaskan bahwa fatwa yang dilansir MUI telah memberikan ruang terbuka bagi masyarakat untuk membincangkannya dari dua sudut pandang, pro dan kontra. Hal ini menegaskan ulang bahwa otoritas MUI sebagai lembaga fatwa pemerintah masih dipertanyakan (Sirry 2013).

Kajian fatwa lainnya dilakukan oleh Nadirsyah Hosen (2004) yang menganalisa fatwa-fatwa yang diterbitkan MUI dalam kurun waktu 1975-1998 dengan pengambilan data melalui interview dengan beberapa pimpinan MUI untuk mendapatkan penjelasan dan komentar terhadap proses lahirnya fatwa. Selain itu, pandangan tokoh di luar MUI juga diperlukan utnuk mendapatkan sudut pandang berbeda terhadap fatwa MUI. Penelitian Hosen fokus menganalisa metode pengambilan fatwa, sumber dan landasan fatwa, hubungan antara fatwa di tingkat nasional dan loka, serta ragam topik fatwa itu sendiri. Hosen menegaskan bahwa MUI sudah melakukan upaya akomoditatif terhadap kepentingan pemerintah dan masyarakat dalam menerbitkan fatwa sehingga diharapkan munculnya kepercayaan dan penerimaan dari setiap kalangan atas fatwa yang diterbitkan, meskipun hal tersebut sangat sulit untuk dicapai karena corak lapisan masyarakat sangat beragam dalam paradigma berpikir dalam beragama. Penelitian Hosen ini memberikan rekomendasi agar MUI melakukan perubahan yang bersifat reformasi dalam metode pengambilan fatwa karena perubahan kondisi sosial, politik, dan ekonomi masyarakat sudah bergeser dari tahun-tahun lalu (Hosen 2004).

Artikel ini hendak mengikuti metode yang dilakukan oleh Kaptein dengan menganalisa landasan fatwa MUI dari sudut kajian ushul fikih untuk mengukur otoritas fatwa tersebut dan melihat respons masyarakat terhadap fatwa tersebut. Karena itu, artikel ini merupakan tindak lanjut dari penelitian Kaptein dengan mengkritisi kesimpulannya bahwa fatwa adalah simbol otoritas keagamaan di Indonesia padahal fatwa MUI tidak mutlak diterima oleh seluruh elemen masyarakat Muslim Indonesia. Artikel ini juga merupakan tindak lanjut dari penelitian Sirry, sekaligus menguatkan kembali kesimpulannya bahwa fatwa MUI dalam masalah politik memiliki tingkat otoritas dan keterimaan yang rendah di kalangan masyarakat karena fatwa tersebut hanya diterima oleh kelompok yang memiliki kepentingan yang sejalan dengan fatwa tersebut. Terakhir, artikel ini akan menguatkan pendapat Hosen bahwa fatwa MUI dalam isu politik harus dirumuskan dengan memperhatikan berbagai macam opini dari kalangan pemerintah dan masyarakat agar dapat diterima dengan baik karena fatwa-fatwa politik MUI selama ini telah menjadi kontroversi masyarakat.

Untuk itu, artikel ini membahas fatwa MUI dengan fokus pada salah satu fatwa MUI yang kontroversial, yakni fatwa tentang haramnya golongan putih 
(golput; tidak memilih atau memberikan suara dalam pemilihan umum) (Hadi 2019; Firdaus 20109; Ani 2019; dan Septianto 2019). Fatwa ini sebetulnya berbunyi "memilih pemimpin yang beriman dan bertakwa, jujur (siddiq), terpercaya (amanah), aktif dan aspiratif (tabligh), mempunyai kemampuan (fathonah), dan memperjuangkan kepentingan umat islam hukumnya adalah wajib" (MUI 2009). Namun, ini kemudian ditangkap oleh masyarakat sebagai fatwa haram Golput karena bahasa media berita (Wulan 2014).

Fatwa haram golput menjadi salah satu sorotan netizen di dunia maya yang diperdebatkan oleh kubu pro dan kontra. Hal ini dimungkinkan sehubungan dengan perkembangan jejaring media sosial sebagai salah satu bagian terpenting dalam kehidupan masyarakat sekarang untuk berkomunikasi dengan banyak orang. Secara umum, media sosial mendemonstrasikan beragam jenis sumber informasi. Selain konten, ada banyak sekali data informasi non-konten yang dapat diperoleh di media sosial seperti tweet di antara konten dari anggota komunitas.

Fatwa haram golput yang dikeluarkan MUI pada tahun 2009 menjadi polemik di kalangan masyarakat pada gelaran Pemilihan Umum tahun 2014 dan 2019. Perdebatan yang paling hangat adalah pada momen Pemilihan Umum 2014 karena banyak fakta yang belum disampaikan oleh MUI terkait fatwa tersebut seperti bahwa fatwa tersebut hanya sekedar anjuran, bukan sebuah perintah keharusan. Pemilihan Umum 2014 juga menjadi Pemilihan Umum pertama yang dihadapi masyarakat setelah fatwa ini dikeluarkan sehingga respons masyarakat dan netizen cukup tinggi.

Artikel ini hendak menjawab permasalahan utama sebagai berikut: Apakah fatwa haram golput MUI tahun 2009 memiliki otoritas? Untuk menjawab pertanyaan ini, artikel ini akan menjawabnya dengan menguraikan dua permasalahan lanjutan, yaitu bagaimana respons netizen Twitter terhadap fatwa haram golput MUI? dan faktor apa saja yang mempengaruhi netizen Twitter untuk menolak dan menerima fatwa tersebut?

Artikel ini berargumen bahwa respons netizen di Twitter terhadap fatwa haram golput MUI dapat dijadikan gambaran otoritas fatwa MUI di tengah masyarakat. Dalam kasus fatwa haram golput MUI tahun 2009 ini, terjadi kontroversi yang cukup kuat di tengah masyarakat di dunia nyata dan dunia media sosial. Pro dan kontra juga mewarnai perdebatan tersebut. Hal ini menggambarkan arus penolakan dan penerimaan yang cukup besar di kalangan masyarakat. Perdebatan ini dapat menggambarkan bahwa otoritas fatwa MUI belum sepenuhnya diterima oleh masyarakat sebagai fatwa yang mengikat dan harus dilaksanakan.

Untuk menjawab pertanyaan di atas, artikel ini melakukan penelitian kuantitatif dan kualitatif. Metode kuantitatif dilakukan dalam hal pengambilan 
dan pengorganisasian data, sedangkan kualitatif dilakukan dalam analisa dan interpretasi data. Data yang diperlukan berupa tweet berbahasa Indonesia oleh netizen di Twitter yang dikumpulkan (scraping) dalam periode 1 Januari-8 Juli 2014. Pengambilan data ini menggunakan salah satu modul di Python, yaitu twitter scraper dengan kata kunci "fatwa haram golput mui", "fatwa haram golput", "golput mui", dan "fatwa golput" (Akilandeswari and Rajalakshm: 2018). Kemudian, data yang sudah dikumpulkan tersebut disimpan dalam bentuk Comma Separated Values (CSV) yang selanjutnya digabungkan sesuai dengan periodenya masing-masing untuk dilakukan analisis.

Penelitian ini membutuhkan alur yang terstruktur untuk dapat menghasilkan kesimpulan yang tepat. Setiap proses tahapan penelitian dilakukan dengan cara seksama dan mengikuti kode etik penelitian. Penelitian ini berupaya melakukan penjaringan tweet yang ada untuk dapat dipotret secara komperhensif dan diverifikasi secara keseluruhan. Selanjutnya, proses analisis akan menjadi lebih sederhana dan lebih menggambarkan seluruh tweet yang ada. Alur proses penelitian dari mulai mendapatkan data sampai mendapatkan model yang siap untuk divisualisasikan dan diinterpretasikan dapat dilihat pada Diagram 1.

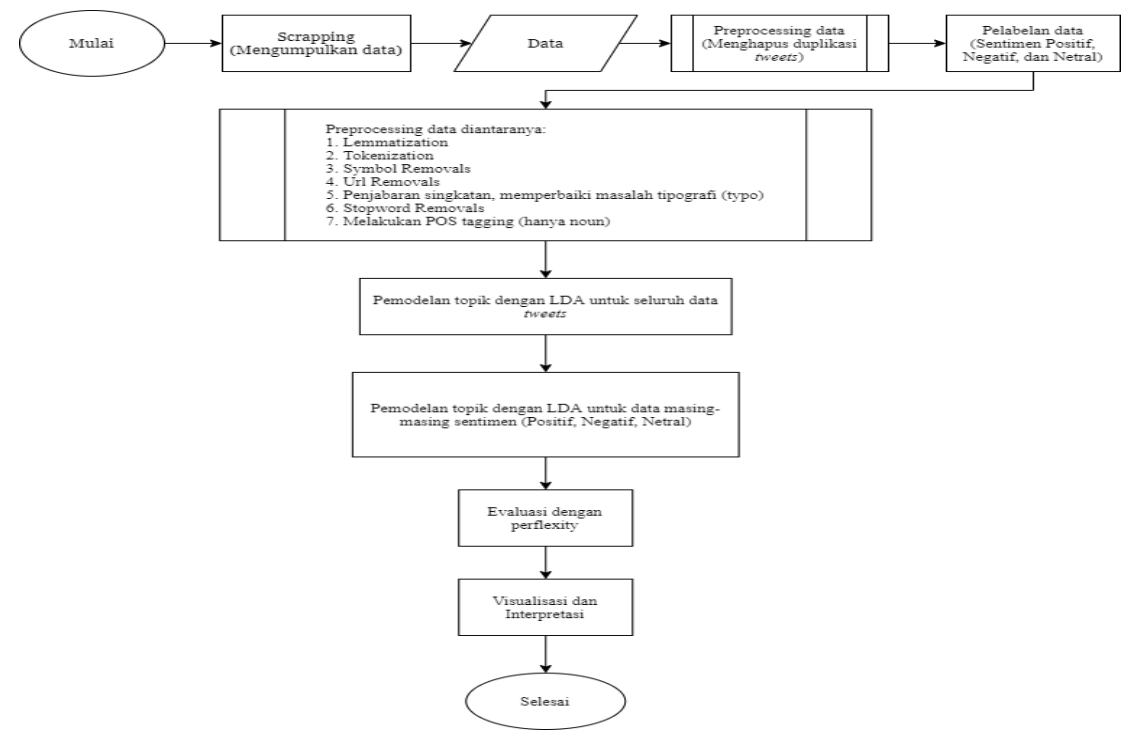

Diagram 1. Alur Penelitian

Artikel ini bertujuan sebagai berikut. Pertama, memperkaya kajian tentang MUI sebagai bentuk kritik untuk memberikan masukan berarti dan bermanfaat dalam perumusan fatwa kepada masyarakat umum. Kedua, memberikan nilai tambah pengkajian Islam dari sudut pandang 
yang tidak normatif dengan mengkaji teks, tetapi menganalisa fenomena respons masyarakat terhadap nilai keagamaan yang beredar di sekitar mereka melalui fatwa yang dikeluarkan oleh MUI atau instansi/organisasi masyarakat keagamaan lainnya. Ketiga, memberikan saran dan kritik terhadap MUI untuk dapat mengevaluasi proses rumusan fatwa yang akan dilansir untuk masyarakat Muslim Indonesia yang dikenal sangat beragam.

\section{Otoritas Sebagai Simbol Kekuatan Lembaga}

Otoritas berarti hak untuk bertindak, berkuasa, dan wewenang (Departemen Pendidikan Nasional 2008:1025). Otoritas dapat dibagi menjadi otoritas koersif dan otoritas persuasif. Koersif adalah kemampuan untuk mengarahkan prilaku dan keyakinan orang lain atas dasar kepercayaan. Otoritas persuasif adalah kemampuan mempengaruhi prilaku dan kepercayaan orang lain dengan meyakinkan orang lain bahwa hal itu adalah hal yang sudah seharusnya dilakukan dan diyakinkan. (Abou El Fadl 2004: 37-43) Menurut Abou El Fadl, penafsiran terhadap Al-Qur'an dan hadis dapat menimbulkan otoritarianisme dalam mengambil alih hak otoritas dengan otoriter dan kesewenang-wenangan.

Ada beberapa asumsi yang melandasi penafsiran terhadap teks. Di antaranya adalah asumsi keimanan, asumsi substantif normatif, asumsi rasional dan asumsi berbasis metodologi (Abou El Fadl 2004: 376). Karena itu, diperlukan tiga hal utama untuk membangun otoritas dalam hukum Islam, yaitu kompetensi (otentitas), penetapan makna, dan pelimpahan otoritas Tuhan. Pelimpahan ini yang akan membukan ruang lahirnya otoritarianisme. Dalam pelimpahan otoritas Tuhan ini, para pemberi fatwa harus memenuhi lima kualifikasi untuk menghindari kemungkinan penyalahgunaan otoritas dan otoritarianisme: pertama, kejujuran dalam memahami perintah Tuhan; kedua, kesungguhan dalam mencurahkan segenap kemampuan rasional dalam berijtihad; ketiga, pengendalian diri dalam proses memahami yang dilandasi dengan sikap batin rendah hati dan tidak emosional; keempat, komperhensif dalam menelusuri kehendak Tuhan; dan kelima, rasionalitas dalam memahami dan menafsirkan perintah Tuhan (Abou El Fadl 2004: 375).

Forth (1981) memiliki pandangan berbeda untuk menentukan kelahiran otoritas seorang individu atau sebuah institusi. Usia, senioritas keturunan, dan kelas adalah tiga unsur yang paling dominan untuk melahirkan otoritas. Dalam kehidupan beragama, otoritas dapat dibangun dengan usia, senioritas, dan kelas. Ketiga unsur tersebut mengalami dinamika yang cukup menarik. Senioritas dalam satu ruang lingkup menjadi faktor 
terkuat meskipun berhadapan dengan usia dan kelas. Jika unsur senioritas berhadapan dengan unsur kelas, maka unsur senioritas akan muncul sebagai landasan utama dari berbagai batasan usia. Begitu juga selanjutnya, jika unsur senioritas berhadapan dengan unsur usia, maka unsur senioritas akan menjadi alat ukur kombinasi dengan kelas yang merupakan kombinasi paling berkualitas. Perlu ditegaskan juga bahwa senioritas dan usia menjadi unsur terkuat dalam melihat otoritas dalam dunia sekuler (Forth 1981: 263264).

\section{MUI dan Fatwa Haram Golput}

MajelisUlamaIndonesia(MUI)adalah sebuah lembaga swadaya masyarakat yang mewadahi ulama, zu'ama, dan cendikiawan Islam di Indonesia untuk membimbing, membina dan mengayomi kaum Muslimin di seluruh Indonesia. MUI berdiri pada tanggal 7 Rajab 1395 Hijriah, bertepatan dengan tanggal 26 Juli 1975 di Jakarta, Indonesia. MUI didirikan pada tahun 1975 oleh presiden Suharto di tengah munculnya ketegangan antara tokoh keagamaan dan pemerintah. Untuk mengendalikan kekuasaannya, Suharto meminta Amir Machmud, Menteri Dalam Negeri ketika itu, untuk mendirikan majelis ulama di 26 provinsi. Kemudian, didirikan MUI Pusat sebagai bentuk koordinasi dengan mengangkat Hamka (Hadji Abdul Malik Karim Amrullah) sebagai ketua pertama (Mudzhar 1993: 47; Bowen 2003: 229).

Pada 2009, MUI mengeluarkan fatwa haram golput yang dirumuskan oleh Majelis Ulama Indonesia dalam Hasil-Hasil Ijtima' Ulama Komisi Fatwa Majelis Ulama Indonesia III Tahun 2009 di Padang Panjang, Komisi A tentang Masail Asasiyah Wathaniyah (Masalah Strategis Kebangsaan) poin 4, Menggunakan Hak Pilih dalam Pemilihan Umum (MUI 2009). Fatwa haram golput ini lahir sebagai respons MUI terhadap meningkatnya angka golput di setiap pelaksanaan Pemilihan Umum sebagaimana terlihat pada Grafik 1 . 


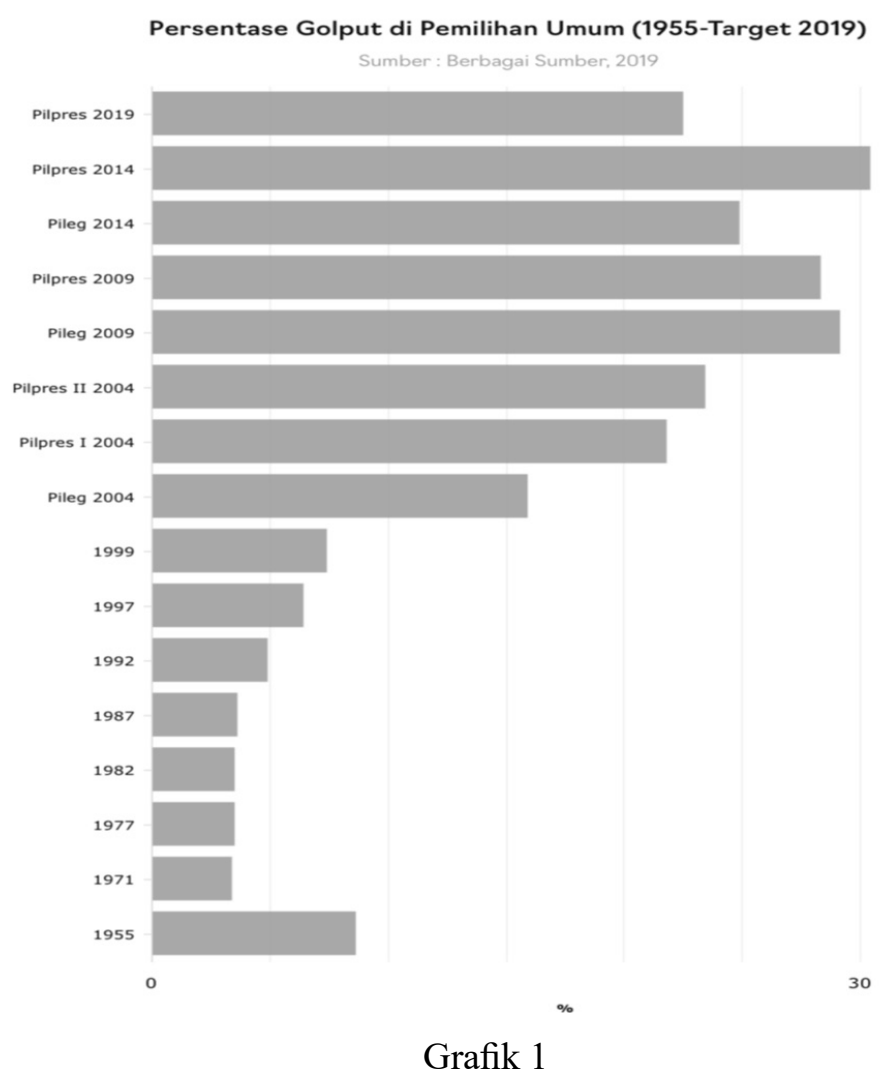

Persentase Golput di Pemilihan Umum 1955-2019 (Katadata: 2019)

Fatwa ini didasarkan pada dua ayat Al-Quran dari surat Al-Nisa', yaitu ayat 58 yang menekankan pentingnya memenuhi amanah dan menegakkan keadilan sebagai kriteria pemimpin yang ideal; dan ayat 59 yang menegaskan kepatuhan umat Islam terhadap perintah para pemimpinnya. Fatwa ini juga dilandasi oleh 11 hadis terkait perjanjian dan sistem yang dirumuskan oleh masyarakat Muslim untuk mengikat mereka dalam bertindak, kepemimpinan baik dan buruk setelah Nabi Muhammad, ba 'iat dan mati jahiliyah, penyerahan amanah kepada yang tidak ahli sebagai tanda kiamat, keharusan patuh kepada pemimpin, etika memilih pemimpin yang lebih pantas dan berhak, merubah kemungkaran dengan kemampuan yang dimiliki, kepatuhan terhadap semua perintah yang bukan maksiat, dan etika bepergian untuk memilih pemimpin. 


\section{Pemetaan Respons Netizen}

Figur 1 menunjukkan lima baris data di 2014 yang terdiri dari waktu melakukan tweet terkait fatwa haram golput MUI, username sebagai pihak yang membuat tweet, retweets yang menunjukkan jumlah banyaknya tweet yang telah dibuat kemudian di bagikan kembali oleh orang lain, likes yang menunjukkan jumlah suka terkait tweet yang dibuat, dan replies menunjukkan jumlah orang membalas tweet tersebut.

\begin{tabular}{|c|c|c|c|c|c|c|}
\hline & timestamp & username & retweets & likes & replies & text \\
\hline 10 & $\begin{array}{r}2014-01-08 \\
06: 56.05\end{array}$ & \#HijrahPeradaban & 0 & 0 & 0 & $\begin{array}{r}\text { IWAN JANUAR - Menanti \#Fatwe \#Politik Nan Sempurna http://goo gl/fb/cEOUk \#artikel \#dakwah \#golput } \\
\text { \#islam }\end{array}$ \\
\hline 11 & $\begin{array}{r}2014-01-13 \\
10: 57: 03\end{array}$ & @prianes & 0 & 0 & 0 & $\begin{array}{l}\text { Golput adalah pilihan politik ! Kenapa harus ada fatwa haram MUI, nggak salah tuh, yg benar adalah ' HarAm } \\
\text { hukumnya untuk Mencoblos ' @NET }\end{array}$ \\
\hline 12 & $\begin{array}{r}2014-01-07 \\
10: 37: 56\end{array}$ & Augy P Harseno & 0 & 0 & 0 & $\begin{array}{l}\text { Tak mau terapkan islam kaffah I tapi waktu dekat pemilu khawatir banyak golput I kenapa minta fatwa dari } \\
\text { islam? }\end{array}$ \\
\hline 13 & $\begin{array}{r}2014-01-07 \\
09: 44: 38\end{array}$ & M Anom Guritno & 0 & 0 & 0 & $\begin{array}{l}\text { Nabi Muhammad ga pernah ngajarin pemilu n demokrasi tuh. MUI jg pernah haramin ngsih duit k pngemis loh } \\
\text { "@F11jn Fatwa MUI golput harem bro.. }\end{array}$ \\
\hline 14 & $\begin{array}{r}2014-01-07 \\
09: 39: 46\end{array}$ & $\begin{array}{r}\text { Firman mano } \\
\text { Saputra }\end{array}$ & 0 & 0 & 1 & $\begin{array}{c}\text { Fatwa MUI golput haram bro. . @ardj03na. Nope...'ll do the best by my way not democrazy way... "@F } 11 \mathrm{jn} \\
\text { Choose the best from the worst" }\end{array}$ \\
\hline
\end{tabular}

\section{Figur 1}

Lima Baris Data pada 2014

Selanjutnya, Figur 2 menunjukkan jumlah tweet terbanyak pada 2014, yaitu pada bulan Maret, diikuti oleh bulan April dan bulan Juli dengan jumlah tweet masing-masing adalah 624, 530, dan 304 tweet. Selain itu, jumlah tweet yang paling sedikit terjadi pada bulan mei dengan jumlah tweet sebanyak 38 tweet. Dari seluruh tweet tentang fatwa haram golput MUI pada periode 2014, total keseluruhannya adalah 1.836 tweet.

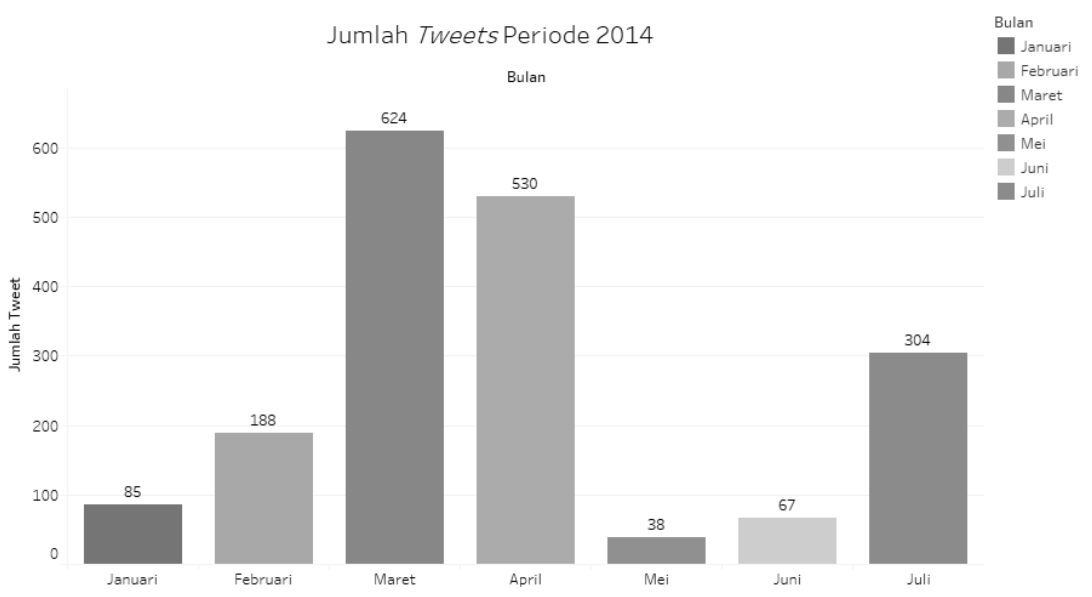

Figur 2

Jumlah Tweet tentang Fatwa Golput pada 2014 (Januari-Juli) 
Dua data di atas menggambarkan bahwa respons netizen dipicu oleh pola responsif terhadap fatwa golput yang dikeluarkan pada tahun 2009 . Pola responsif tersebut sangat besar gelombangnya di 2014 pada saat Pemilihan Umum pertama dilaksanakan setelah keluarnya fatwa haram golput di tahun 2009.

Tweet yang terkumpul ini kemudian dikelompokkan berdasarkan sentimen yang muncul dalam tiga kelompok, yaitu sentimen negatif, sentiment netral, dan sentimen positif. Hasil pengelompokkan tersebut adalah 825 tweet mengandung sentimen negatif, 830 tweet mengandung sentimen netral, dan 181 tweet mengandung sentimen positif. Angka ini sesuai secara akumulasi, yaitu 1.836 tweet.

Respons netral (sebanyak 830) lebih banyak dari pada respons negatif dan positif. Respons negatif (sebanyak 825) lebih banyak dari pada respon positif. Respons positif adalah respons yang paling sedikit dengan jumlah 181 tweet.

Jika dilihat dari hasil pengelompokkan tersebut, kemudian dianalisa dengan mendeteksi kata-kata yang dominan dalam tweet tersebut, maka hasilnya dapat dilihat dalam beberapa data di bawah ini.

Figur 3 menunjukkan bahwa sebaran kata-kata pada tweet di 2014 didominasi oleh kata "golput" yang disebutkan sebanyak 2.119 kali, kata "MUI" disebutkan sebanyak 1.582 kali, kata "haram" disebutkan sebanyak 1.445 kali, dan kata "fatwa" disebutkan sebanyak 1.226 kali. Selain itu, kata "pilih" dan "yang" disebutkan sebanyak kurang-lebih 500 kali. Kata "dosa", "keluarkan", dan "ulama" disebutkan lebih dari 100 kali. Kata-kata "wajib", "hukumnya", "komisi”, "pimpinan", "hak", "Islam”, "agama”, "manusia", "milih", dan "haramkan" disebutkan lebih dari 60 kali. 


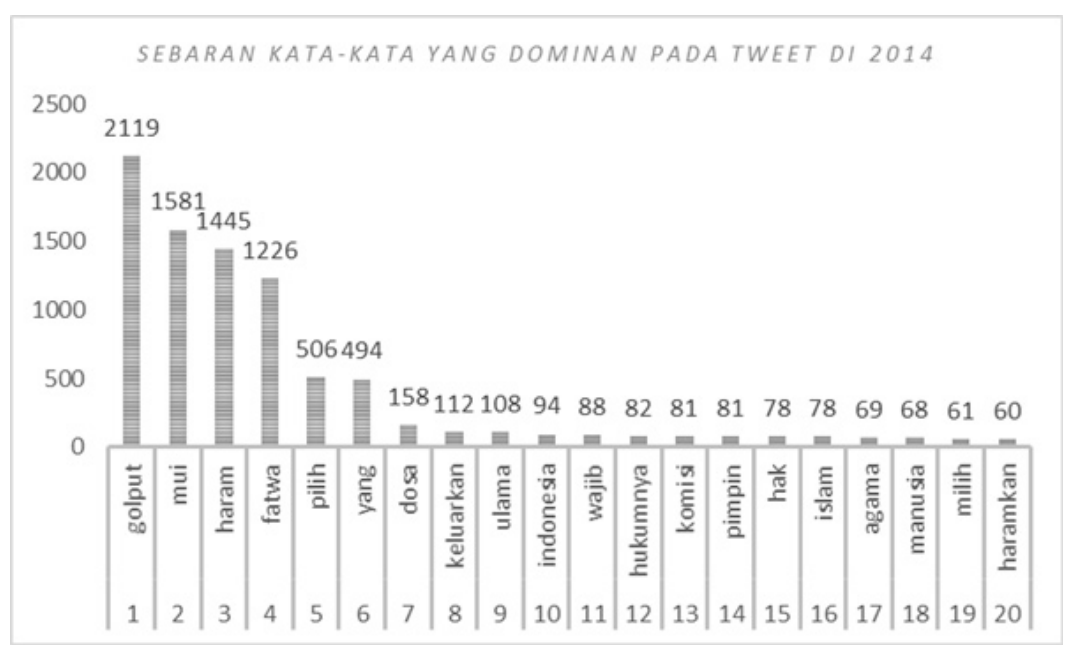

Figur 3

Sebaran Kata-kata yang Dominan pada Tweet di 2014

Sebagaimana dalam Figur 4, sebaran kata dalam tweet dengan sentimen negatif pada 2014 didominasi kata "golput" yang disebutkan sebanyak 963 kali, kata "haram" yang disebutkan sebanyak 769 kali, kata "MUI" disebutkan sebanyak 663 kali, dan kata "fatwa" disebutkan sebanyak 639 kali. Selain itu, kata "pilih" disebutkan sebanyak 203 kali, kata "dosa" disebutkan lebih dari 50 kali, dan kata-kata "hak", "milih", "halal", "keluarkan", "komisi", "manusia", "bilang", "demokrasi", "detikcom", "nyoblos", “ulama", "wajib", "politik", dan "Islam" masingmasing disebutkan lebih dari 20 kali. 


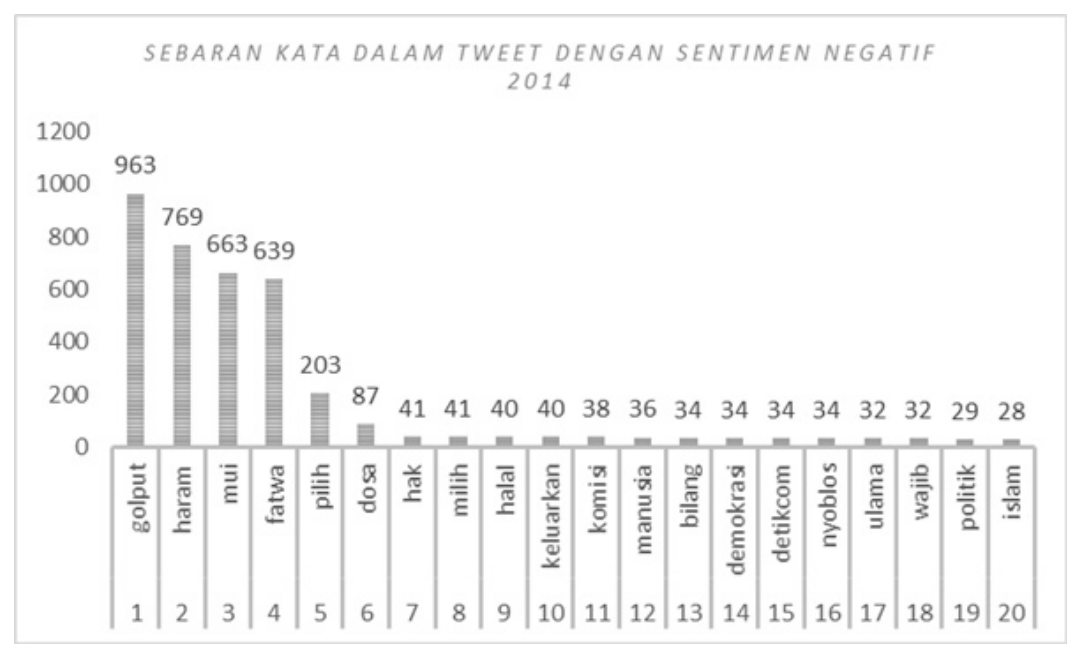

Figur 4

Sebaran Kata dalam Tweet dengan Sentimen Negatif di 2014

Figur 5 menunjukkan bahwa sebaran kata dalam tweet dengan sentimen netral pada periode 2014 didominasi kata "golput" yang disebutkan sebanyak 948 kali, kata "MUI" yang disebutkan sebanyak 749 kali, kata "haram" disebutkan sebanyak 589 kali, kata "fatwa" disebutkan sebanyak 487 kali. Selain itu, kata "pilih" disebutkan sebanyak 230 kali, dan kata-kata "dosa", "keluarkan", "Indonesia", "ulama", dan "hukumnya" disebutkan lebih dari 50 kali. Kata-kata "pimpin", "berita", "komisi", "haramkan", "Islam", “wajib", "majelis", "Jabar", dan "umat" disebutkan kurang dari 50 kali. 


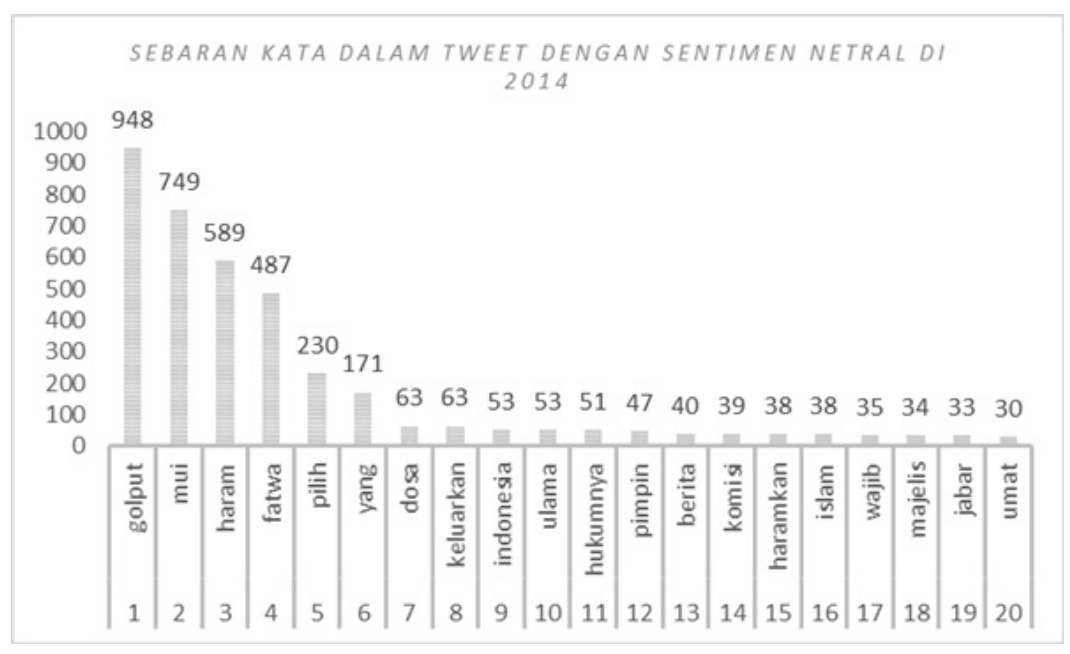

Figur 5

Sebaran Kata dalam Tweet dengan Sentimen Netral di 2014

Pada Figur 6, sebaran kata pada tweet dengan sentimen positif pada 2014 didominasi oleh kata "golput" yang disebutkan sebanyak 206 kali, kata "MUI" disebutkan sebanyak 169 kali, kata "fatwa" disebutkan sebanyak 100 kali, dan kata "haram" disebutkan sebanyak 87 kali. Selain itu, kata "pilih" disebutkan sebanyak 73 kali. Kata-kata "ormas", "agama", "ulama", dan "wajib" disebutkan lebih dari 20 kali. Kata-kata "Indonesia", "pimpin”, "hak", "masyarakat", "Islam", "majelis", "politik", "keluarkan", "manusia", "dosa", dan "hukumnya" disebutkan kurang dari 20 kali. 


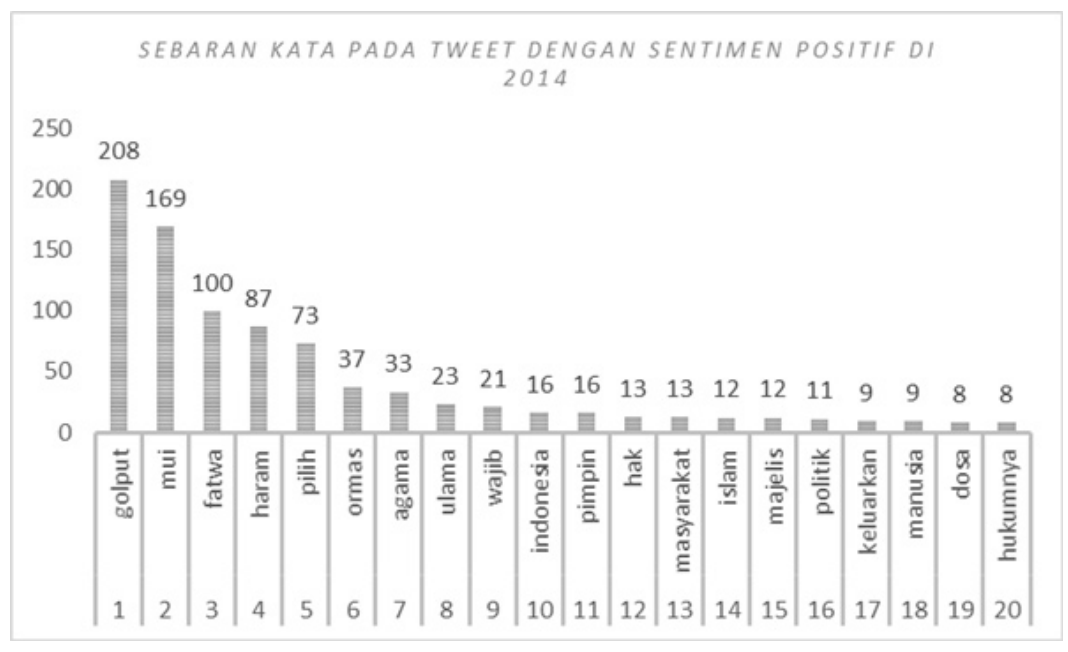

Figur 6

Sebaran Kata dalam Tweet dengan Sentimen Positif 2014

Dari perbandingan di atas, terdapat empat kata yang dominan di mayoritas sentiment, yaitu "golput", "MUI", "fatwa", dan "haram". Hal ini menunjukkan bahwa tweet yang beredar membahas isu fatwa haram golput masih dalam tahap diskusi yang fokus dan tidak memperlebarkan pada isu-isu lainnya. Kata-kata yang muncul secara dominan ini dapat menjadi tafsiran atas polarisasi respons netizen terhadap fatwa haram golput MUI.

Hal ini bisa menggambarkan bahwa diskusi fatwa haram golput MUI di tahun 2014 diwarnai dengan isu pembahasan keagamaan tentang hukum golput dari perspektif rumusan fatwa yang dilansir MUI dalam ranah pengambilan dalil dari Al-Qur'an dan hadis, penggunaan kaidah-kaidah fikih, serta pengutipan pendapat ulama klasik, meskipun nuansa politik dalam perdebatan respons netizen tetap muncul di tahun 2014.

Fakta-fakta di atas menegaskan ulang bahwa fatwa MUI secara umum kerap menjadi bahan diskusi dan perdebatan di kalangan masyarakat (Sirry 2013:116-117), bahkan sering disebutkan sebagai fatwa yang tidak konsisten dan alat kekuasaan politik (Sarip 2019: 289-298). Fatwa haram golput juga muncul dengan dinamika kontroversi masyarakat secara luas (Hadi 2019). 


\section{Pemetaan Respons Netizen dalam Wordcloud dan Wordlink}

Pemetaan sebaran kata dalam respons netizen Twitter terhadap fatwa haram golput MUI pada periode 2014 di atas dianalisa dengan metode Wordcloud dan Wordlink yang dapat memberikan gambaran tentang isu yang paling dominan diperbincangkan oleh netizen dan jaringan keterkaitan respons netizen tersebut untuk melihat topik-topik yang diangkat dalam perbincangan netizen dan seberapa kuat pengaruhnya terhadap perpolitikan di Indonesia.
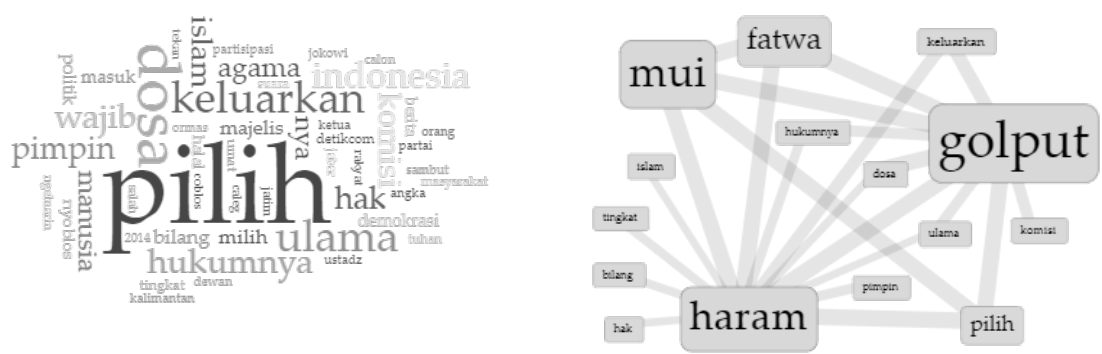

Figur 7

Respons Netizen di Tweet terhadap Fatwa Golput MUI dalam Wordcloud dan Wordlink

Sebagaimana terlihat pada Figur 7, respons sebagian besar netizen tentang fatwa haram golput MUI pada 2014 bernuansakan negatif dengan sindiran terhadap fungsi fatwa sebagai alat politisasi kekuasaan sehingga fatwa ini dianggap sebagai fatwa politik yang lahir dari sebuah desakan kepentingan politik tertentu, bukan fatwa keagamaan yang lahir dari problem di tengah masyarakat Muslim di Indonesia. Hal ini menimbulkan diskusi netizen tentang fatwa haram golput MUI dengan sudut pandang politik. Ajang Pemilihan Presiden (Pilpres) 2014 merupakan persaingan dua kandidat presiden, Jokowi dan Prabowo, sehingga ketegangan politik menjadi lebih besar dibandingkan Pilpres sebelumnya. Karena itu, segala topik yang muncul di tengah masyarakat menjadi pembahasan dan perdebatan panjang antara pendukung kedua calon presiden tersebut. Isu fatwa haram golput MUI juga tidak luput dari sorotan netizen dalam bingkai politik.

Bentuk sentimen negatif lainnya muncul dengan mempertanyakan konsep dosa dalam golput yang dibandingkan dengan memilih pemimpin yang salah, sehingga muncul pertanyaan kritis apakah dosa golput lebih 
kecil dibandingkan dosa memilih pemimpin yang salah jika memberikan hak pilih saat Pemilihan Umum (Pemilu).

Di sisi lain, respons netizen juga muncul dengan kacamata sosial yang melihat bahwa fatwa haram golput MUI ini sekedar akal-akalan MUI untuk mencari ruang di tengah masyarakat yang sedang diguncang perbedaan arus politik mejelang Pilpres dalam Pemilihan Umum 2014. Fatwa ini dimunculkan agar MUI mendapatkan sorotan dan perhatian kembali dari masyarakat karena MUI dinilai telah mengalami penurunan kepercayaan dengan adanya isu korupsi dalam proses sertifikasi halal MUI dan lain sebagainya.

Para pengamat politik termasuk Siti Zuhro dari Lembaga Ilmu Pengetahuan Indonesia (LIPI) menilai bahwa fatwa haram golput yang dilontarkan MUI pada tahun 2009 terlalu berlebihan karena tidak ada landasan hukum yang kuat dan tepat untuk memperkuat fatwa tersebut (Saifulloah: 2014). Fatwa MUI tidak dapat dijadikan dasar kuat dalam bernegara seperti undang-undang dan produk hukum positif yang ditetapkan pemerintah melalui DPR. Namun, fatwa MUI apat dijadikan sebagai doktrin perundang-undangan yang dijadikan materi dalam pembentukan hukum negara. Artinya, fatwa MUI itu sendiri tidak bisa dijadikan alat mendorong dan memaksa melaksanakan ketentuan yang tertuang dalam fatwa seperti fatwa haram golput, tetapi fatwa haram golput MUI dapat dijadikan sumber hukum materil guna melahirkan undangundang kewajiban memberikan hak suara dalam Pemilu (Sarip 2019).

\section{Respons Netral Netizen}

Pada Figur 8, tampak bahwa respons netral yang dilontarkan netizen di 2014 atas fatwa haram golput masih seputar isu keagamaan, khususnya terkait perihal fatwa haram yang dipahami dengan konsekuensi dosa jika tidak dipatuhi. Senada dengan ini, respons beberapa ahli pendidikan juga memberikan masukan kepada MUI untuk meningkatkan tingkat partisipasi masyarakat dalam Pemilu. Karena itu, mereka memberikan saran bahwa edukasi kepada masyarakat yang baik adalah dalam bentuk arahan dan sosialisasi secara informatif tentang pentingnya memberikan hak suara dalam Pemilu (Saifulloh 2014). 

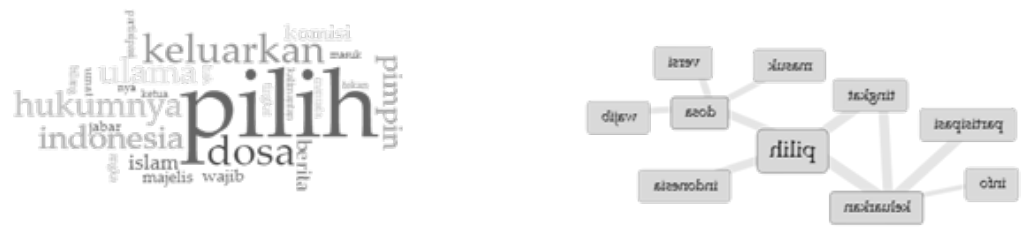

Figur 8

Respons Netral Netizen terhadap Fatwa Haram Golput MUI dalam Worlcloud dan Wordlink

Sehubungan ini, Yakobus, salah seorang politisi PDIP menyatakan bahwa "Masyarakat perlu diberikan pendidikan politik lebih cerdas, dan cara-cara berpolitik di jaman Orde Baru harus diubah. Jangan hanya mengejar kekuasaan untuk mendapatkan kekuasaan, tetapi betul-betul mau memperjuangkan rakyatnya" (Wibisono 2009). Pandangan yang sama disampaikan oleh pakar hukum dan kenegaraan Jimly Asshiddiqie yang waktu itu menjabat Ketua Dewan Kehormatan Penyelenggara Pemilu (DKPP) yang menegaskan bahwa fatwa ini terlalu keras bagi masyarakat, meskipun niatnya baik dan luhur untuk meningkatkan perhatian dan partisipasi masyarakat dalam Pemilu (Prabowo 2014).

Untuk meningkatkan partisipasi masyarakat dalam Pemilu, ada beberapa upaya yang dapat dilakukan seperti penguatan pentingnya Pemilu dan ajakan untuk partisipasi dalam Pemilu. Langkah-langkah ini sudah terbukti berhasil diterapkan oleh Komisi Pemilihan Umum (KPU) Kota Payakumbuh dalam meningkatkan partisipasi masyarakat dalam Pemilihan Walikota dan Wakil Walikota tahun 2017. KPU Kota Payakumbuh melakukan penguatan dengan menggandeng beberapa pihak seperti organisasi masyarakat, event erganizer, dan lain sebagainya untuk menggelar kegiatan bersifat sosialisasi pentingnya pemilihan pemimpin. Mereka juga menggelar kegiatan yang bersifat hiburan tradisional untuk masyarakat supaya tertarik mengikuti proses pemilihan pemimpin daerah. Selain itu, mereka juga menggelar kegiatan talkshow dan dialog kepada masyarakat untuk memberikan pemahaman yang mendalam terkait kegiatan pemilihan pemimpin daerah (Indra 2019: 426-430).

Respons netral netizen terlihat dalam contoh tweet sebagai berikut:

"Mau nyoblos takut salah pilih, mau golput takut dosa.... (Fatwa MUI: GolPut itu haram ) Any suggestion ?" (Syamsul Bahri, https:// twitter.com/CokiAjaa/status/448086841707614209). 
"Pengennya seh golput kepengen milih takut fatwa MUI haram golput pengen partisipasi yang ptg kliatan bilik suara" (Queen of Heart, https://twitter.com/QueenOfHeart20/status/436445256838443008).

\section{Respons Negatif Netizen}

Sebagaimana tergambar pada Figur 9, fatwa haram golput MUI mendapatkan banyak respons negatif dari netizen pengguna Twitter. Hal tersebut tergambar dari pola kata-kata yang muncul dari berbagai tweet yang ada. Sebagian kata dihubungkan dengan istilah-istilah politik seperti hak, demokrasi, dan pilih. Selain itu, istilah-istilah keagamaan juga muncul seperti halal, wajib, Islam, ulama, dan lain sebagainya. Kata "hak" berhubungan dengan kata "versus" yang menandakan adanya opini dari netizen bahwa fatwa ini bertentangan dengan hak warga negara untuk memberikan suara atau tidak memberikan suara pada Pemilu.
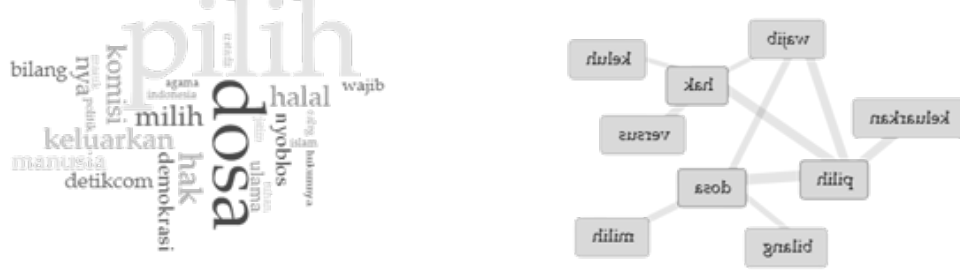

Figur 9

Respon Negatif Netizen terhadap Fatwa Haram Golput MUI dalam Wordcloud dan Wordlink

Beberapa komentar memberikan sentimen negatif dengan memelintir istilah golput menjadi "golongan penerima uang tunai", bukan "golongan putih". Hal ini menggambarkan bahwa netizen memiliki perhatian terhadap fenomena perpolitikan di Indonesia yang kerap diwarnai dengan politik uang. Karena itu, fatwa haram golput ini lebih tepatnya dihubungkan kepada orang-orang yang terlibat dalam praktik money politic.

Di sisi lain, respons negatif dihubungkan dengan sosok para calon pemimpin yang tidak memenuhi kualifikasi pemimpin yang baik. Hal ini menggambarkan bahwa fatwa haram golput justru akan memberikan problem kebangsaan baru, bukan memberikan solusi. Karena itu, fatwa ini justru akan menjerumuskan masyarakat ke dalam jurang dosa karena memilih pemimpin yang tidak baik. Hal ini menggambarkan bahwa diskusi fatwa haram golput dengan nuansa sentimen negatif berputar dalam 
ranah keagamaan tentang hukum memilih pemimpin, khususnya memilih pemimpin yang tidak baik.

Di sisi lain, respons negatif juga hadir dari kelompok anti demokrasi seperti Hizbut Tahrir Indonesia (HTI) dengan diskusi keagamaan yang menghubungkan hukum golput dan memberikan hak pilih dalam ajang Pemilu dengan sistem demokrasi yang menjadi landasan pelaksanaan Pemilu. Menurut HTI, golput tidak haram, bahkan wajib karena yang haram justru ikut serta memberikan suara dalam Pemilu yang dibangun di atas sistem demokrasi yang tidak sesuai dengan ajaran Islam (VOAIslam 2014). Kelompok HTI juga menegaskan bahwa fatwa ini harusnya berbunyi "wajib golput" karena fatwa MUI sangatlah rancu dan mengandung multi tafsir. Fenomena golput sebagian besar, menurut HTI, lahir dari kekecewaan masyarakat atas sistem demokrasi dan hasil Pemilu yang tidak memberikan dampak positif bagi kesejahteraan masyarakat (Nahimunkar 2014). Karena itu, mereka memandang bahwa fatwa ini mengandung unsur kepentingan politik.

Tokoh besar Nahdlatul Ulama yang pernah menjabat sebagai presiden Republik Indonesia, Abdurrahman Wahid, menyampaikan kritik terhadap fatwa haram golput MUI. Ia menolak orang atau institusi yang mengatasnamakan MUI untuk mengeluarkan fatwa haram golput (Antara 2009).

Respon negatif pengguna Twitter terhadap fatwa haram golput MUI terlihat, misalnya, dalam beberapa tweet berikut ini:

"Golputitu HARAM.Yg singkatan golputnya adlh Golongan Penerima Uang Tunai. Kalau golongan putih tidak diberi fatwa oleh MUI" (Fitria Afrianni, https://twitter.com/pitliaa/status/453746944947392512).

"MUI mengeluarkan fatwa HARAM GOLPUT. Kalo misalkan para kandidat nggak ada yang bener, berarti MUI sudah melakukan dosa besar." (Ilham Rahmadhani, https://twitter.com/IlhamSebelas/ status/452442564755329026).

\section{Respons Positif Netizen}

Figur 10 menunjukkan respons positif yang diberikan oleh pengguna Twitter terhadap fatwa haram golput MUI. Fatwa ini dipahami sebagai sebuah arahan yang tidak memaksa dan sebagai sebuah anjuran untuk berpartisipasi dalam Pemilu. 

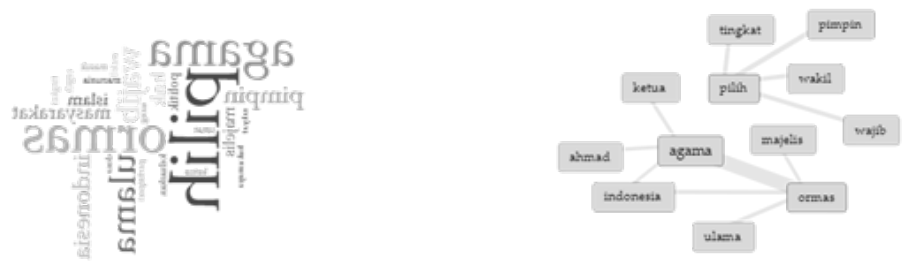

Figur 10

Respons Positif Netizen atas Fatwa Haram Golput MUI dalam Wordcloud dan Wordlink

Hal ini senada dengan pengamat politik seperti Afifuddin selaku Koordinator Nasional Jaringan Pendidikan Pemilih untuk Rakyat (JPPR) yang menyatakan bahwa fatwa golput haram sebenarnya hanya sebatas imbauan untuk mendongkrak partisipasi masyarakat. Selain itu, aturan memilih adalah hak dan bukan kewajiban warga negara. Yang perlu dilakukan MUI adalah mengajak tokoh-tokoh agama untuk mengimbau masyarakat agar memilih dan mempercayakan adanya perubahan (Saifulloh 2014).

Keharaman golput dijelaskan oleh ketua komisi fatwa MUI Jabar, Umar Salim, disebabkan adanya calon pemimpin yang memenuhi syarat dan layak dipilih. Jika ada pemimpin yang memenuhi syarat dan layak dipilih, maka golput haram. Jika tidak ada calon pemimpin yang memenuhi syarat dan layak dipilih, maka golput tidak haram (Prabowo 2014).

Di sisi lain, keharaman golput juga diperkuat oleh pernyataan tokoh-tokoh keagamaan dari organisasi masyarakat seperti Ghazali An Naqsabandy dari Tareqat Naqsabandiyah Jabal Qubis Tanjung Morawa yang menegaskan bahwa: "Umat Islam jangan golput pada Pemilu 2014. Pilihlah calon wakil rakyat yang seakidah". Ia juga menegaskan bahwa provokasi golput merupakan upaya musuh Islam untuk membuat Islam tidak memiliki peranan penting dan strategis dalam kekuasaan di negara ini (Analisa Daily 2014).

Ketua MPR, Hidayat Nur Wahid, juga mengamini fatwa tersebut dengan mengatakan bahwa: "Fatwa itu tidak berlebihan karena sekarang ada seorang tokoh menyuruh golput". Selain itu, ia bependapat bahwa jika fatwa ini efektif dan diterima masyarakat, maka jumlah pemilih akan meningkat sehingga terjadi peningkatan kualitas demokrasi di Indonesia (Viva 2008). 
Hal ini dibantah oleh ketua DPR, Agung Laksono, yang mengatakan bahwa: "Pemilu itu adalah hak masyarakat. Saya tidak setuju golput diharamkan". Di sisi lain, ia tetap mendorong masyarakat untuk memberikan hak pilih dengan memilih wakil rakyat dan para pemimpin bangs aini (JPNN 2009). Mendengar komentar tersebut, Hidayat Nur Wahid menjawab bahwa DPR harus mendukung fatwa haram golput yang merupakan produk hukum keagamaan MUI karena DPR juga membuat undang-undang keagamaan yang akan didukung oleh MUI. Ia juga menegaskan bahwa fatwa ini bukan produk politisasi MUI.

Tuduhan fatwa ini lahir sebagai bentuk politisasi agama juga lahir karena dalil-dalil ayat Al-Qur'an dan hadis yang digunakan tidak memiliki keterkaitan dengan kewajiban memilih pemimpin dan keharaman golput. Karena itu, fatwa haram golput MUI dapat diperkuat dengan pengkajian penelusuran sejarah politik Islam jika teks-teks keagamaan berupa AlQur'an dan hadis tidak dapat memberikan jawaban secara langsung dengan ketetapan yang jelas (Azam 2020).

Secara metodologis, fatwa haram golput MUI yang dibangun di atas metode penetapan hukum Islam dengan landasan Al-Qur'an, hadis, konsensus ulama, analogi hukum Islam, pendapat ulama, kaidah ushul fikih. Fatwa ini memiliki dasar-dasar dari teks keagamaan Al-Qur'an dan hadis dengan pemahaman kontekstual karena perbedaan kondisi sosial pada saat Al-Qur'an dan hadis tersebut turun dan terucap dengan kondisi sosial permasalahan golput hadir di Indonesia. Terdapat banyak kritik atas pemahaman teks keagamaan yang digunakan MUI dalam melandasi fatwa haram golput sehingga menjadi bahan kontroversi di kalangan masyarakat, khususnya warga netizen Twitter (Hariono 2018).

Di sisi lain, kemunculan fatwa haram golput MUI ini tidak lepas dari peran masyarakat keagamaan dan politikus Islam di Indonesia. Dari unsur politik, PKS memiliki andil besar dalam lahirnya fatwa ini melalui salah satu kader terbaiknya, yaitu Hidayat Nur Wahid yang saat itu menjabat sebagai ketua MPR. PKS sebagai partai Islam sendiri juga menggerakkan jaringan dakwahnya di tengah masyarakat untuk mendorong pemerintah mengeluarkan ketentuan wajib memilih bagi seluruh masyarakat Indonesia. PKS melalui beberapa jaringan media dakwah Islam seperti Sabili telah memproduksi wacana-wacana keagamaan tentang haramnya golput dan keajiban memberikan hak pilih dalam ajang Pemilu bagi seluruh masyarakat Indonesia (Wicaksono 2011). Dari fakta ini, beberapa pengamat melihat adanya kepentingan politik dari salah satu partai politik yang identik dengan partai keagamaan untuk meningkatkan jumlah peraihan suaranya menggunakan tangan fatwa MUI. 
Kritik lainnya hadir dari pengamat politik Arbi Sanit. Ia mengatakan bahwa tokoh politik yang mendukung fatwa haram golput merupakan tokoh yang antidemokrasi. Ia menganalogikan hal tersebut dengan gaya kepemimpinan Orde Baru yang memaksa masyarakat untuk berpartisipasi dalam Pemilu dengan kekuatan politik senjata. Karena itu, jika ada paksaan dari pemerintah dan tokoh politik nasional kepada masyarakat untuk memberikan suara dan pilihannya dalam Pemilu, maka hal itu merupakan warisan dari gaya kepemimpinan Orde Baru yang otoriter (Detik 2008; JPPN 2009).

Menurut Mahfud MD, kesuksesan Pemilu memang bisa dikaitkan dengan tingkat partisipasi masyarakat yang tinggi dan golput yang rendah, tetapi tidak akan mempengaruhi legalitas hasil Pemilu itu sendiri (Setyawan 2019). Menurut Direktur Eksekutif Lokataru Foundation, Haris Azhar, golput adalah bentuk ekspresi dan partisipasi politik seseorang (Aisyah 2019).

Dalam aspek sosial, fatwa haram golput MUI telah memberikan wacana baru di tengah masyarakat dalam menghadapi kontestasi Pemilu yang tidak sekedar untuk mendukung salah satu calon pemimpin semata, tetapi untuk memberikan perhatian terhadap kegiatan Pemilu itu sendiri. Tidak dapat dipungkiri bahwa keberhasilan demokrasi sebuah negara dapat diukur salah satunya dengan tingkat partisipasi masyarakat dalam ajang Pemilu (Hasbillah 2015).

Menurut Denny JA dari LSI, ada empat faktor yang bisa menurunkan angka golput pada Pemilu 2019. Pertama, mobilisasi dan seruan "jangan golput" kubu Jokowi dan Prabowo yang masif di akhir-akhir masa kampanye. Kedua, munculnya partisipasi aneka civil society yang juga membuat gerakan antigolput. Ketiga, tingginya partisipasi segmen pemilih minoritas dengan berbagai alasan, salah satunya merasa terancam dengan narasi politik identitas yang menggaung di salah satu kubu. Keempat, berbagai gerakan door to door campaign atau get out the vote masingmasing kandidat, terutama kubu Jokowi melalui aneka relawannya yang masif di ujung masa kampanye (Boy 2019).

Bagi pemilih remaja pada khususnya, kepercayaan kepada calon pemimpin menjadi faktor utama yang dapat meningkatkan atau menurunkan angko golput di kalangan remaja. Kepercayaan politik dapat dilihat dari tiga aspek, yaitu kemampuan calon pemimpin, kebajikan calon pemimpin, dan integritas calon pemimpin (Mensana 2019: 33-34).

Fatwa haram golput sendiri belum terbukti secara akademik dapat meningkatkan partisipasi masyarakat dalam Pemilu atau menurunkan angka 
golput. Namun, para peneliti menyimpulkan bahwa fatwa MUI memiliki peran penting dalam menggiring opini publik terhadap permasalahan sosial dan pilitik sehingga fatwa MUI terkadang sengaja dibentuk untuk kepentingan politik (Menchik 2019). Fatwa haram golput ini akan sangat berpengaruh pada kelompok tradisional yang mana menurut teori otoritas Weber fatwa memiliki otoritas yang bersifat radisionalis, artinya sangat mudah diterima dan diikuti oleh kelompok tradisional (Menchik 2019).

Tweet yang menggambarkan respon positif terhadap fatwa haram golput MUI dapat dilihat dalam contoh-contoh berikut:

"Udah ada fatwa dari MUI kalo golput itu haram. Sok atuh jangan golput..." http://www.dakwatuna.com/2014/02/27/46938/muigolput-termasuk-perbuatan-dosa/ ... (Nur Istiqomah I, https:// twitter.com/NistiqomahI/status/446922153594593280).

"Ratusan ribu surat suara dicetak, tapi gk ada yg nyoblos, merasa tdk dihargai kami Mas". *panitia pemilu luar negeri*Golput haram (fatwa MUI 08) (Kieren Akbar, https://twitter.com/kierenakbar/ status/453728838149603330).

\section{Kesimpulan}

Artikel ini telah menunjukkan bahwa respons netizen di media sosial, khususnya Twitter, terhadap fatwa haram golput oleh MUI pada Pilpres 2014 sangat beragam dengan sentimen negatif, netral, dan positif. Dari jumlah keseluruhan tweet yang berhasil didapatkan sebanyak 1.836 tweet, sentimen negatif berjumlah 830 tweet, sentimen netral berjumlah 825 tweet, dan sentimen positif berjumlah 181 tweet.

Sentimen negatif dapat dipersepsikan bahwa mereka menolak fatwa tersebut, sedangkan sentimen positif dapat dipersepsikan menerima fatwa tersebut. Sentimen netral mengindikasikan tidak menolak dan tidak menerima karena jika mereka memilih golput atau memilih tidak menjadikan fatwa tersebut sebagai dasar.

Respons yang beragam tersebut dilatar-belakangi oleh beberapa faktor. Di antaranya adalah faktor kecenderungan politik, kecenderungan keagamaan, dan faktor kecenderungan konflik sosial.

Beberapa topik yang mewarnai diskusi netizen dalam membincang fatwa haram golput ini adalah isu tentang hukum golput dalam pandangan Islam, dosa antara memilih golput dan pemimpin yang tidak baik, dan politisasi fatwa MUI. Fatwa haram golput memiliki celah untuk menjadi bahan kontroversi di tengah masyarakat. Masyarakat belum sepenuhnya 
menerima fatwa haram golput karena mereka percaya adanya kepentingan tertentu di balik fatwa ini. Akibatnya, otoritas MUI sebagai lembaga fatwa di Indonesia belum sepenuhnya diterima oleh masyarakat, khususnya dalam konteks fatwa yang menyinggung isu politik kebangsaan.

\section{Pendanaan}

Penelitian ini mendapat bantuan dana dari Pusat Penelitian dan Penerbitan (PUSLITPEN) Universitas Islam Negeri Syarif Hidayatullah Jakarta, melalui Program Penelitian Dasar Interdisipliner tahun anggaran 2019.

\section{Ucapan Terima}

Penulis mengucapkan terima kasih kepada Pusat Penelitian dan Penerbitan (PUSLITPEN) Universitas Islam Negeri Syarif Hidayatullah Jakarta yang telah memberikan kesempatan dan dukungan pendanaan untuk penelitian ini dan semua reviewer atas komentar berharga mereka.

\section{Referensi}

Abou El Fadl, Khaled M. 2004. Atas Nama Tuhan: Dari Fikih Otoriter ke Fikih Otoritatif .Terj. R. Cecep Lukman Yasin. Jakarta: Serambi Ilmu Semesta.

Aisyah, Dian. 2019. "Haris Azhar: Golput Tidak Melanggar Aturan, KPU Jangan Membatasi”. Bandung Kita, Februari 22. Diakses dari (https://bandungkita.id/2019/02/22/haris-azhar-golput-tidakmelanggar-aturan-kpu-jangan-membatasi/).

Akilandeswari, J. dan K. Rajalakshm. 2014. "A Survey on Knowledge Analytics of Text from Social Media". International Journal of Computer Science and Business Informatics 13(1): 45-61.

Admin. 2014. "Syech H Ghazali An Naqsabandy: Umat Islam Kota Medan Diimbau Tidak Golput" Analisadaily, Maret 07. Diaksed dari (https://analisadaily.com/berita/arsip/2014/3/8/11949/syech-hghazali-an-naqsabandy-umat-islam-kota-medan-diimbau-tidakgolput/).

Ani. 2019. "MUI Luruskan soal Fatwa Golput Haram". CNN Indonesia, Maret 28. Diakses dari (https://www.cnnindonesia.com/ nasional/20190328113845-32-381395/mui-luruskan-soal-fatwagolput-haram). 
Antara News. 2009. "Gus Dur Tolak Fatwa Haram Golput”. Antara News, Januari 27. Diakses dari (https://www.antaranews.com/ berita/2656/gus-dur-tolak-fatwa-haram-golput).

Anwar, Syamsul. 2005. "Fatwa, Purification and Dynamization: A Study of Tarjih in Muhammadiyah". Islamic Law and Society 12(1): 27-44.

Assyaukanie, Luthfi. 2009. "Fatwa and Violence in Indonesia". Journal of Religion and Society 1: 1-21.

Azam. 2020. "Pemahaman Hadis Majlis Ulama Indonesia (MUI): Telaah atas Fatwa tentang Pemilu". Kontemplasi 08(01): 75-103.

Barton, Greg dan Greg Fealy. 1996. Nahdlatul Ulama: Traditionalist Islam and Modernity in Indonesia. Monash: Monash Asia Institute.

Boy. 2019. "4 Penyebab Angka Golput Pemilu 2019 Cukup Rendah". $J P N N$, Mei 03. Diakses dari (https://www.jpnn.com/news/4penyebab-angka-golput-pemilu-2019-cukup-rendah?page=2).

Bowen, John R. 2003. Islam, Law and Equality in Indonesia : An Antropology of Public Reasoning. Cambridge: Cambridge Universityy Press.

Detik. 2008. "Usulkan Fatwa Haram Golput, Hidayat Nur Wahid Anti Demokrasi". Detik, Desember 13. Diakses dari (https://news. detik.com/berita/d-1053139/usulkan-fatwa-haram-golputhidayat-nur-wahid-anti-demokrasi).

Firdaus, Randy Ferdi. 2019. "Fatwa Haram Golput dari MUI yang Membingungkan". Merdeka, Maret 27. Diakses dari (https:// www.merdeka.com/politik/fatwa-haram-golput-dari-mui-yangmembingungkan.html).

Forth, Gregory L. 1981. "The Division of Authority". An Ethnographic Study of a Traditional Domain in Eastern Sumba. Edited by Rindi. Leiden: Brill.

Hadi, Usman. 2019. "Kontroversi Fatwa Haram Golput". Detik, Maret 27. Diakses dari (https://news.detik.com/berita-jawatengah/d-4484979/kontroversi-fatwa-haram-golput).

Hariono, Dui. 2018. "Hadis dalam Pusaran Pemilu: Mengkaji Pemahaman Hadis MUI dalam Fatwa Haram Golput Pemilu". Universum 12(1): 21-32. 
Hasbillah, Ahmad Ubaidi. 2015. "Fatwa Haram Golput dalam Perspektif Sosiologi Hukum Islam”. Yudisia 6(1): 1-23.

Hosen, Nadirsyah. 2004. "Behind the Scenes: Fatwas of Majelis Ulama Indonesia (1975-1998)." Journal of Islamic Studies 15(2): 147179.

Ibn Manzhur, Muhammad ibn Makram. 1414 H. Lisan al-'Arab. Beirut: Dar al-Shadir.

Indra, Deky Syukma, Alfan Miko, dan Asmawi. 2019. "Strategi Sosialisasi Komisi Pemilihan Umum dalam Meningkatkan Partisipasi Pemilih pada Pemilihan Walikota dan Wakil Walikota Payakumbuh Tahun 2017". JISPO 9(1): 413-430.

JPPN. 2009. "Ketua DPR Tolak Fatwa Golput Haram”. JPNN, Januari 28. Diakses dari (https://www.jpnn.com/news/ketua-dpr-tolakfatwa-golput-haram?page=2).

Kaptein, Nico J.G. 2004. "The Voice of the Ulama: Fatwas and Religious Authority in Indonesia." Archives de sciences sociales des religions 49(125): 115-130.

Menchik, Jeremy. "The Politics of the Fatwa". Diakses dari (https:// jeremymenchik.files.wordpress.com/2019/02/menchik_politics_ fatwa_mui_indonesia.pdf).

Mensana, Ferdinal dan Ersa Lanang Sanjaya. 2019. "Kepercayaan Politik dan Intensi Memilih: Prilaku Politik Pemilih Remaja Akhir di Surabaya Menjelang Pemilu 2019." JISPO 10(1): 23-37.

MUI. 1981. Fatwa Majelis Ulama Indonesia tentang Merayakan Natal Bersama. Jakarta: Majelis Ulama Indonesia.

MUI. 2009. Fatwa Munas VII Majelis Ulama Indonesia. Jakarta: Majelis Ulama Indonesia.

MUI. 2009. Hasil-hasil Ijtima' Ulama Komisi Fatwa Majelis Ulama Indonesia III. Padang Panjang: Majelis Ulama Indonesia.

MUI. “Sejarah MUI”. Diakses dari (https://mui.or.id/sejarah-mui/).

Mudzhar, Mohammad Atho. 1993. Fatwa-fatwa Majelis Ulama Indonesia. Jakarta: INIS.

Nahi Munkar. 2014. "Teks Fatwa MUI Soal Golput dan Pidato Para Penentangnya". Nahimunkar, April 3. Diakses dari (https://www. nahimunkar.org/teks-fatwa-mui-soal-golput-dan-pidato-parapenentangnya/). 
Prabowo, Dani. 2014. "Fatwa MUI Soal Golput Haram Terlalu Keras". Kompas, Maret 30. Diakses dari (https://nasional.kompas.

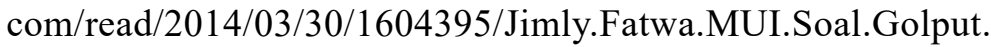
Haram.Terlalu.Keras).

Saifulloah, Muhammad. 2014. "Fatwa Haram Golput Dianggap Berlebihan". Okenews, April 01. Diakses dari (https://news. okezone.com/read/2014/04/01/568/963545/fatwa-haram-golputdianggap-berlebihan).

Sarip, Diana Fitriana, dan Elya Kusuma Dewi. 2019. "Mendudukkan Fatwa Majelis Ulama IndonesiaSebagai Doktri Perundang-Undangan". Jurnal Legislasi Indonesia 16(3): 289-298.

Septianto, Bayu. 2019. "Kontroversi Fatwa Haram Golput yang Dikampanyekan MUI". Tirto, Maret 26. Diakses dari (https:// tirto.id/kontroversi-fatwa-haram-golput-yang-dikampanyekanmui-dkig).

Setyawan, Feri Agus. 2019. "Mahfud MD: Golput Itu Hak, Secara Hukum Tak Masalah". CNN, Maret 28. Diakses dari (https:// www.cnnindonesia.com/nasional/20190328152024-32-381484/ mahfud-md-golput-itu-hak-secara-hukum-tak-masalah).

Sirry, Mun'im. 2013. "Fatwas and their Controversy: The Case of the Council of Indonesian Ulama (MUI)". Journal of Shouteast Asian Studies 44(01): 100-117.

Viva News. 2008. "Hidayat Dukung Fatwa Haram Golput". Viva News, Desember 12. Diakses dari (https://www.viva.co.id/arsip/15333hidayat-dukung-fatwa-haram-golput).

VOA Islam. 2014. "Berlandaskan Demokrasi, Haram Mengikuti Pemilu". VOA Islam, Maret 26. Diakses dari (https://www.voa-islam.com/ $\mathrm{read} /$ indonesiana/2014/03/26/29648/berlandaskan-demokrasiharam-mengikuti-pemilu/).

Wahid, Abdurrahman. 1981. "Fatwa Natal, Ujung dan Pangkal". Tempo, Mei 30, h. 17.

Wibisono, Kunto. 2009. "Yakobus: Fatwa Haram Golput MUI Langgar HAM". Antara News, Februari 06. Diakses dari (https://www. antaranews.com/berita/132096/yakobus-fatwa-haram-golputmui-langgar-ham).

Wicaksono, Denison. 2011. "Kontestasi Wacana Golput pada Media Islam Menjelang Pemilu 2009". Dimensia 5(1): 15-44. 
Wulan, R. Teja. 2014. "MUI Keluarkan Fatwa Haram Golpit, Partisipasi Pemilih Meningkat". Voaindonesia, Maret 21. Diakses dari (https://www.voaindonesia.com/a/mui-keluarkan-fatwa-haramgolput-partisipasi-pemilih-meningkat/1876637.html).

Al-Zabidi, Muhammad ibn Muhammad ibn Abdul Razaq. t.t. Tāj al-'Arūs min Jauhar al-Qāmūs. Kairo: Dar al-Hidayah. 
